\title{
Konsepsi siswa kelas tiga sekolah dasar tentang bilangan bulat
}

\author{
Syafdi Maizora ${ }^{1,2}$ * iD , Rizky Rosjanuardi ${ }^{2}$ \\ 1 Program Studi Pendidikan Matematika, Universitas Bengkulu, Bengkulu, Indonesia \\ 2 Departemen Pendidikan Matematika, Universitas Pendidikan Indonesia, Bandung, Indonesia \\ * Corresponding Author. E-mail: syafdiichiemaizora@unib.ac.id
}

\begin{tabular}{|c|c|}
\hline CLE INFO & ABSTRACT \\
\hline $\begin{array}{l}\text { Article History: } \\
\text { Received: } 11 \text { Jan. } 2021 \\
\text { Revised: } 18 \text { Jan. } 2021 \\
\text { Accepted: } 01 \text { Feb. } 2021 \\
\text { Keywords: } \\
\text { Bilangan bulat, } \\
\text { Bilangan bulat negatif, } \\
\text { Konsepsi matematika, } \\
\text { Siswa kelas 3 SD, } \\
\text { Integers, } \\
\text { Negative integers, } \\
\text { Mathematical conception, } \\
\text { Third-grader elementary } \\
\text { school. }\end{array}$ & $\begin{array}{l}\text { Artikel ini menggambarkan konsepsi salah seorang siswa kelas } 3 \text { Sekolah Dasar di Kota Bengkulu } \\
\text { tentang bilangan bulat di luar pembelajaran formal. Siswa ini mengalami banyak intervensi } \\
\text { tanpa skenario dalam pembelajarannya, di antaranya dari keluarga (kakak kelas } 8 \text { yang memiliki } \\
\text { prestasi baik dalam matematika, kedua orang tua pengajar matematika) dan pelatihan sempoa. } \\
\text { Konsepsi yang digali adalah arti bilangan negatif, bilangan bulat, serta operasi penjumlahan dan } \\
\text { pengurangan pada bilangan bulat. Jenis penelitian ini adalah penelitian kualitatif dengan pen- } \\
\text { dekatan studi kasus. Subjek diberikan beberapa pertanyaan seputar konsepsi bilangan bulat. } \\
\text { Hasil penelitian menunjukkan bahwa subjek memiliki konsepsi sebagai berikut: 1) menggunakan } \\
\text { istilah "kurang", "utang" atau "posisi di bawah permukaan" untuk memaknai bilangan bulat ne- } \\
\text { gatif, 2) bilangan bulat negatif diartikan sebagai invers penjumlahan bilangan asli, 3) ada perbe- } \\
\text { daan antara simbol negatif dengan simbol operasi pengurangan, 4) bilangan bulat negatif bera- } \\
\text { da di sebelah kiri bilangan 0 pada garis bilangan, 5) bilangan bulat negatif terkecil berada di sebe- } \\
\text { lah kiri bilangan bulat negatif lainnya, seperti bilangan-bilangan pada penggaris, dan mampu } \\
\text { menggunakan dinding sebagai pengganti garis bilangan, 6) menggunakan istilah "maju" atau } \\
\text { "mundur" untuk mengoperasikan penjumlahan bilangan bulat, 7) menggunakan kata "jarak", } \\
\text { "lompatan di atas garis bilangan", dan "lompatan di bawah garis bilangan" untuk mengoperasi- } \\
\text { kan pengurangan bilangan bulat. }\end{array}$ \\
\hline 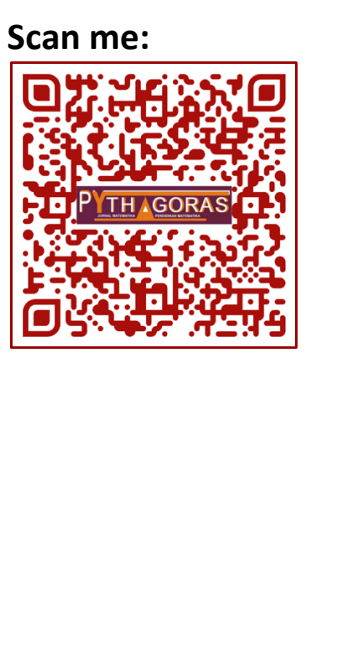 & $\begin{array}{l}\text { This article described the conception of a third-grader elementary school in the City of Bengkulu } \\
\text { about integers outside formal learning. This student experienced many interventions without } \\
\text { scenarios in their learning, including their families (a brother in eighth-graders who had good } \\
\text { mathematics achievements, parents were mathematics education lecturer) and an abacus trai- } \\
\text { ning. The explored conceptions were the meaning of negative numbers, integers, and addition } \\
\text { and subtraction operations on integers. This research was qualitative research with a case study } \\
\text { approach. The subject was asked several questions regarding the conception of integers. The } \\
\text { results of this research indicated that the subject had the following conception: 1) using the term } \\
\text { "less", "debt", or "position under the surface" to interpret negative integers; 2) interpreting nega- } \\
\text { tive integers as the inverse of the addition of natural numbers; 3) differentiating the negative } \\
\text { symbol and the subtraction operation symbol, 4) locating negative integers to the left of "0" on a } \\
\text { number line; 5) locating smaller negative integers to the left of other negative integers like num- } \\
\text { bers on a ruler and having an ability to use a wall as a substitute of a number line; 6) using terms } \\
\text { "forward" or "backward" to operate integer additions; and 7) using the term "distance", "jumps } \\
\text { over the number line", and "jumps under the number line" to operate integer subtractions. }\end{array}$ \\
\hline
\end{tabular}

This is an open access article under the CC-BY-SA license (cC)(i) (2)

\section{How to Cite:}

Maizora, S., \& Rosjanuardi, R. (2020). Konsepsi siswa kelas tiga sekolah dasar tentang bilangan bulat. Pythagoras: Jurnal Pendidikan Matematika, 15(2), 201-215. https://doi.org/10.21831/pg.v15i2.37645 


\section{PENDAHULUAN}

Pada Kurikulum 2013, berdasarkan Permendikbud Nomor 37 Tahun 2018 tentang Perubahan Atas Peraturan Menteri Pendidikan dan Kebudayaan Nomor 24 Tahun 2016 tentang Kompetensi Inti dan Kompetensi Dasar Pelajaran pada Kurikulum 2013 pada Pendidikan Dasar dan Pendidikan Menengah (Kemendikbud, 2018), pengenalan bilangan bulat mulai diajarkan pada kelas 1, yakni bilangan cacah sampai 99. Selanjutnya pada kelas 2, bilangan cacah sampai 999. Pada kelas 3, siswa dituntut untuk menguasai sifat-sifat operasi hitung bilangan cacah. Pada saat kelas 6, baru diperkenalkan bilangan bulat negatif dengan Kompetensi Dasar 3.1 yaitu menjelaskan bilangan bulat negatif (termasuk menggunakan garis bilangan). Artinya, pelajaran pertama tentang bilangan bulat negatif diperoleh siswa mulai dari kelas 6 .

Banyak laporan dari berbagai tempat bahwa siswa sekolah dasar yang telah belajar materi operasi hitung bilangan bulat masih melakukan kesalahan. Di Kota Palopo, Sulawesi, Saputri (2018) melaporkan bahwa hanya 14,59\% dari 35 siswa kelas 5 yang memenuhi KKM yakni 70 untuk materi operasi hitung penjumlahan dan pengurangan bilangan bulat. Di Kota Malang, Nuraini et al. (2016) melaporkan bahwa dari 67 siswa kelas VI pada tiga sekolah dasar yang dilakukan tes diagnostik, $61 \%$ melakukan kesalahan pada operasi penjumlahan bilangan pecahan dan 63,3\% melakukan kesalahan pada operasi pengurangan bilangan pecahan. Di Bali, di SD Gugus XIV Buleleng, nilai rata-rata ulangan pada materi operasi penjumlahan dan pengurangan bilangan bulat di tiga sekolah dasar masih di bawah KKM (Mulyani et al., 2018).

Pada sisi lain, Astawa et al. (2016) menyimpulkan bahwa proses pembelajaran bilangan bulat pada kelas 5 sudah dapat berjalan dengan kategori tinggi. Artinya, tidak ada permasalahan pada proses pembelajaran bilangan bulat. Ada faktor lain yang belum dimaksimalkan dalam pembelajaran, salah satunya adalah kemampuan awal. Kemampuan awal siswa dapat mempengaruhi hasil belajar matematika siswa (Hanun, 2010; Mallewai, 2016). Kemampuan awal siswa dapat dikelola untuk meningkatkan hasil belajar matematika. Artikel ini mengemukakan salah satu kemampuan awal berupa konsepsi siswa terhadap materi bilangan bulat bagi siswa kelas tiga sekolah dasar.

Konsepsi dapat siswa dipengaruhi oleh lingkungan siswa belajar. Lingkungan belajar di antaranya adalah peran orang tua, bimbingan belajar, dan fasilitas belajar yang dimiliki siswa. Pravitasari (2020) melaporkan bahwa terdapat pengaruh partisipasi aktif orang tua terhadap penguasaan konsep kognitif matematika. Partisipasi orang tua berupa dorongan motivasi dan bimbingan belajar selama siswa di rumah. Pada masa pandemi ini, partisipasi orang tua sangat berpengaruh karena pembelajaran dilakukan di rumah bersama orang tua. Di sisi lain, bimbingan belajar juga mempengaruhi secara signifikan dalam tingkat pemahaman konsep matematika siswa (Murjiyanti, 2017). Karena bimbingan belajar memberikan pengulangan dan memperluas materi bagi siswa setelah memperoleh materi di sekolah. Fasilitas belajar yang digunakan siswa sehari-hari juga mempunyai hubungan positif yang signifikan terhadap prestasi belajar matematika siswa (Aji, 2017). Salah satu fasilitas yang sangat berperan adalah jaringan internet. Sumber belajar di dalam jaringan internet sangat banyak tersedia. Siswa dapat mengaksesnya tanpa batas. Fasilitas belajar yang melimpah ini mempengaruhi konsepsi siswa tentang materi matematika.

Konsepsi siswa tentang bilangan bulat dapat terbentuk karena digunakan dalam kehidupan siswa sehari-hari. Dalam arti, konsep bilangan bulat secara tidak langsung dapat dimiliki siswa dari lingkungan meski belum dipelajari. Siswa telah menggunakan operasi hitung bilangan bulat pada permainan sehari-harinya, misal dalam permainan kelereng, siswa sudah dihadapkan pada operasi hitung penjumlahan dan pengurangan bilangan bulat. Jika siswa memberikan sejumlah kelereng ke teman, maka bagi siswa tersebut, jumlah kelereng yang dimiliki berkurang, dan bagi temannya, terjadi penambahan jumlah kelereng.

Kemampuan penerimaan pembelajaran dipengaruhi oleh konsepsi siswa terhadap konsep yang disampaikan pada materi pelajaran. Simon (2016) menyatakan bahwa konsepsi matematika didefinisikan sebagai model penjelasan yang dihasilkan oleh pengajar untuk menjelaskan aturan termasuk pengucapan dari siswa yang belajar matematika dalam hal apa yang dipikirkannya, diketahuinya, dan dipahaminya. Kusaeri (2017) menyatakan bahwa konsepsi adalah pemahaman yang dimiliki siswa dari hasil membaca atau mendengar penjelasan guru tentang suatu konsep.

Konsepsi awal siswa tentang materi yang sedang dipelajari sering diabaikan oleh guru. Guru memulai materi baru tanpa mengetahui apakah siswa sudah mengetahui atau belum materi tersebut. Ini terlihat dari rencana pelaksanaan pembelajaran. Tidak ada bagian menggali informasi yang sudah diketahui oleh siswa pada bagian awal 
pembelajaran. Padahal kemampuan awal dapat mempengaruhi hasil belajar siswa, jika dipadukan dengan metode tertentu (Hanun, 2010; Mallewai, 2016).

Seorang siswa kelas 3 sekolah dasar di Kota Bengkulu, diduga telah memiliki konsepsi matematika tentang bilangan bulat. Dari informasi awal, diperoleh bahwa siswa tersebut mampu mengurutkan bilangan bulat dengan baik. Gambar 1 menyajikan hasil penelusuran kemampuan awal siswa dalam mengurutkan bilangan bulat yang diberikan oleh peneliti. Dari hasil penelusuran tersebut, diperoleh bahwa siswa tersebut mampu mengurutkan dua bilangan bulat dengan baik.

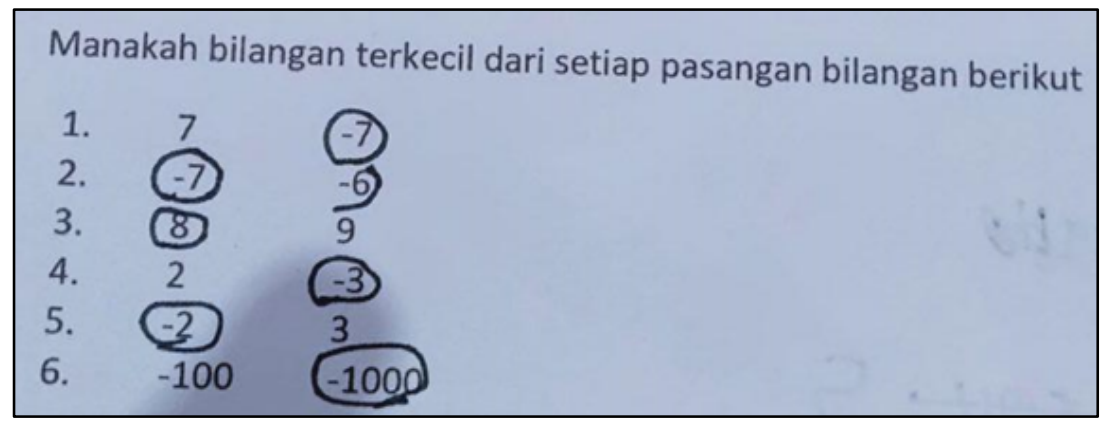

Gambar 1. Kemampuan awal subjek dalam mengurutkan dua bilangan bulat

Siswa tersebut mendapatkan intervensi dalam pembelajaran matematika dari lingkungannya. Siswa ini tinggal bersama seorang kakak yang sedang menempuh kelas 8 SMP dan kedua orang tuanya berprofesi sebagai dosen di Program Studi Pendidikan Matematika. Kakaknya memiliki kemampuan matematika yang lebih, terlihat dari hasil capaian belajarnya, yakni memperoleh nilai 100 pada Ujian Nasional tingkat sekolah dasar. Selain belajar dari rumah, siswa ini juga belajar di salah satu bimbingan belajar yang fokus pada kemampuan berhitung. Namun, sampai saat ini, siswa ini tidak pernah memperoleh prestasi belajar yang tinggi di sekolah.

Adanya faktor intervensi belajar dan kemampuan awal yang dimiliki siswa tersebut, mengakibatkan peneliti tertarik untuk melakukan penggalian informasi lebih lanjut tentang konsepsi bilangan bulat yang dimiliki oleh siswa tersebut. Mulai dari pemaknaan terhadap konsep bilangan bulat, konsepsi apa saja yang dimiliki, dan prosedur operasi hitung yang dilakukannya. Sugiatno (2013) mengungkap bahwa konsepsi siswa tentang operasi hitung bilangan bulat cenderung pada soal kontekstual bersifat personal dan yang dialami siswa. Belum ada penelitian yang mengungkap konsepsi siswa tentang bilangan bulat pada kondisi dimana materi tersebut belum dipelajarinya di sekolah. Berdasarkan hal tersebut, penelitian ini bertujuan untuk menggambarkan konsepsi matematis salah seorang siswa kelas 3 sekolah dasar di Kota Bengkulu tentang bilangan bulat yang dimilikinya di luar pembelajaran formal. Siswa tersebut diberikan pertanyaan-pertanyaan yang mengarah pada pemaknaan bilangan bulat yang dimilikinya. Batasan materi bilangan bulat yang digali pada subjek meliputi arti bilangan bulat negatif, urutan bilangan bulat, keberadaan bilangan bulat negatif sebagai invers penjumlahan bilangan bulat positif, operasi penjumlahan bilangan bulat, dan operasi pengurangan pada bilangan bulat serta maknanya. Dari penelitian ini diharapkan pendidik dapat mempertimbangkan konsepsi yang telah dimiliki siswa untuk merancang pembelajaran bilangan bulat yang efektif.

\section{METODE}

\section{Desain Penelitian}

Penelitian ini adalah penelitian deskriptif kualitatif dengan pendekatan studi kasus. Creswell et al. (2007) menyatakan bahwa penelitian deskriptif kualitatif dengan pendekatan studi kasus digunakan untuk menggali suatu pemahaman yang mendalam tentang masalah unik yang terjadi untuk memperoleh wawasan baru. Pendekatan studi kasus dipilih agar dapat menggali pemahaman yang dimiliki oleh subjek yang belum mempelajari materi bilangan bulat untuk memperoleh wawasan baru tentang konsepsi yang dimilikinya. Subjek diberikan beberapa pertanyaan mendasar tentang permasalahan bilangan bulat. Semua pertanyaan dibantu dengan lembaran-lembaran naskah untuk menggali atau mengkonfirmasi setiap jawaban dari subjek. 


\section{Subjek Penelitian}

Subjek penelitian adalah seorang siswa kelas 3 sekolah dasar yang berumur 8 tahun. Penelitian dilakukan dari tanggal 22 Oktober sampai dengan 15 November 2020 di tempat tinggal subjek, yakni Kota Bengkulu. Tidak ada prestasi yang menonjol dari subjek sejak menjadi siswa sekolah dasar. Siswa tinggal di lingkungan keluarga yang kedua orang tuanya sehari-hari berprofesi sebagai pengajar matematika. Saudara subjek yang berumur 13 tahun sekolah di SMP di Kota Bengkulu kelas 8. Saudara subjek memiliki rekam jejak yang baik dalam penguasaan matematika, salah satunya penerima penghargaan atas raihan nilai 100 pada mata pelajaran matematika saat Ujian Nasional di sekolah dasar. Subjek sering berinteraksi dengan anggota keluarga untuk belajar matematika. Subjek pernah mengenyam pelatihan sempoa selama satu tahun sebelum masa pandemi. Namun, subjek tidak memiliki rekam prestasi yang menonjol selama mengikuti pelatihan sempoa tersebut.

\section{Teknik Pengumpulan Data}

Penelitian ini dimulai dari pengujian kemampuan mengurutkan bilangan bulat. Setelah diketahui bahwa subjek memiliki kemampuan mengurutkan bilangan bulat, maka dilakukan penggalian kemampuan subjek tentang konsepsi bilangan bulat. Proses penelitian dilakukan dengan cara memberikan pertanyaan-pertanyaan tentang bilangan bulat kepada subjek, dilanjutkan dengan melakukan wawancara berdasarkan hasil jawaban yang diberikan oleh subjek. Aspek-aspek yang ditanyakan kepada subjek meliputi: 1) pemaknaan bilangan bulat negatif, 2) bilangan bulat negatif sebagai invers penjumlahan bilangan asli, 3) bilangan bulat negatif dan simbol operasi pengurangan, 4) letak bilangan bulat negatif pada garis bilangan bulat, 5) urutan bilangan bulat, 6) operasi penjumlahan pada bilangan bulat dan maknanya, dan 7) operasi pengurangan pada bilangan bulat dan maknanya. Pertanyaan dilakukan secara berulang dengan pertanyaan yang berbeda namun memiliki tingkatan yang sama. Untuk setiap aspek pertanyaan, subjek diberikan beberapa soal esai sekaligus untuk dijawab. Pengerjaan soal dilakukan di hadapan peneliti untuk langsung dilanjutkan dengan wawancara. Banyak soal yang diberikan kepada subjek sangat bergantung pada variasi soal yang memungkinkan untuk mendapatkan hasil penyelidikan yang maksimal. Hasil jawaban diperiksa kebenarannya dan dilanjutkan penggalian mendalam dengan wawancara. Jika dari hasil wawancara belum ditemukan kesimpulan yang kuat, dilakukan kembali pemberian soal sesuai kebutuhan penggalian informasi. Kemudian dilakukan kembali wawancara mendalam berdasarkan hasil jawaban yang baru. Waktu pengerjaan soal disesuaikan dengan kecepatan subjek menyelesaikan soal tersebut. Pengulangan dapat dilakukan di lain hari dengan menyesuaikan kondisi kesediaan subjek. Hal ini dilakukan untuk memperoleh konsistensi jawaban dari subjek. Setelah diperoleh data yang konsisten dari subjek, dilakukan penarikan kesimpulan.

Instrumen yang digunakan adalah naskah soal sesuai aspek yang akan digali dan daftar pertanyaan untuk wawancara. Data yang diperoleh berupa lembar jawaban subjek di atas kertas terhadap naskah soal yang diberikan dan catatan tangan peneliti atas jawaban-jawaban pertanyaan saat wawancara. Kedua data saling terkait dan menjadi satu kesatuan utuh. Hasil kesimpulan yang diperoleh dari kedua kelompok data tersebut, selanjutnya dikelompokkan berdasarkan tingkatan materi bilangan bulat. Kesimpulan yang dihasilkan berupa konsepsi-konsepsi yang dimiliki subjek berdasarkan instrumen yang diberikan.

\section{Analisis Data}

Analisis data diawali dengan melakukan kondensasi data hasil penelitian untuk memfokuskan, menyederhanakan, dan abstraksi hasil uji tertulis dan wawancara. Kondensasi data mengacu pada proses pemilihan, pemfokusan, penyederhanaan, abstraksi, dan/atau transformasi data yang muncul dalam korpus lengkap (badan) catatan lapangan tertulis, transkrip wawancara, dokumen, dan materi empiris lainnya (Miles et al., 2014). Hasil yang diperoleh dikelompokkan berdasarkan materi bilangan bulat dan disampaikan berdasarkan kelompok tingkatan materi bilangan bulat.

\section{HASIL PENELITIAN}

\section{Pemaknaan Bilangan Bulat Negatif}

Subjek sudah mengetahui bahwa ada bilangan bulat negatif. Subjek mengartikan bilangan negatif sebagai bilangan "yang berkurang" (yang kurang). Menggunakan kata "berkurang" karena nilai yang dimaksud adalah banyaknya bilangan yang kurang dari titik 0 . Namun, ketika diminta memberikan arti dari kata "kurang" dalam kehidupan sehari-hari, subjek menyebut sebagai utang. Kata "utang" muncul ketika bilangan-bilangan diartikan dalam 
permainan kelereng dan subjek dibuat kalah dan harus memberikan kelereng ke peneliti melebihi dari kelereng yang dimiliki subjek.

\section{Kronologis muncul kata "utang"}

Pada saat subjek masih mengartikan bilangan negatif dengan kata "yang berkurang", kemudian disederhanakan dengan kata "kurang", peneliti masih melakukan penggalian makna yang ada dalam kehidupan sehari-hari subjek. Untuk itu peneliti melakukan tanya jawab sebagai berikut.

Peneliti : Mari kita main kelereng ya, aturan mainnya adalah jika adik menang dalam suit, maka adik akan mendapatkan kelereng sebanyak kelereng yang dimiliki saat itu. Jika adik kalah suit, maka adik harus memberikan kelereng ke ayah sebanyak kelereng yang ayah miliki.

Subjek :Oke, ayo!

Peneliti : Kelereng ada 5, ayah pegang 3, adik pegang 2.

Subjek :Oke.

Kemudian dilakukan suit. Diperoleh hasil seri, sama-sama telunjuk. Kemudian diulangi suit kedua, subjek kalah dari peneliti. Berikut perbincangan antara peneliti dan subjek setelah subjek kalah suit.

Peneliti : ayo berikan 3 kelereng ke ayah!

Subjek : Adik hanya punya 2 kelereng, tidak bisa memberi ayah 3 kelereng.

Peneliti : Sesuai janji permainan, yang kalah harus memberi kelereng sebanyak yang dimiliki yang menang kan?

Subjek : lya, tapiadik hanya punya 2 kelereng.

Peneliti : Bagaimana dengan 1 kelereng lagi?

Subjek : Adik utang dulu 1 kelereng ke ayah.

Peneliti : Jadi, kalau 2 kelereng dikurangi 3 kelereng, hasilnya berapa adik?

Subjek : Kurang 1 kelereng.

Peneliti : Kurang 1 kelereng artinya apa itu dik?

Subjek : Utang 1 kelereng.

Untuk memastikan apa yang dipahami subjek, peneliti memberikan permasalahan yang baru yakni, $7-8$ seperti Gambar 2.

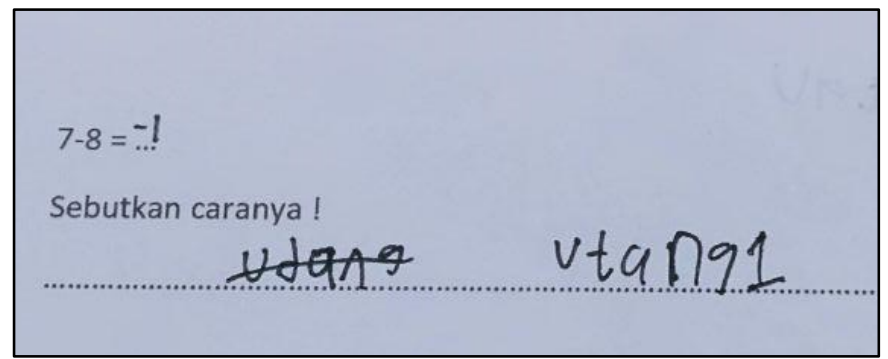

Gambar 2. Pemaknaan utang untuk bilangan negatif

Berdasarkan Gambar 2 terlihat bahwa kata utang langsung mengisi kata "kurang" yang dikemukakan sebelumnya oleh subjek.

Untuk permasalahan kontekstual berikut, tentang posisi suatu benda yang berada di atas permukaan kolam dan benda yang berada pada posisi di bawah permukaan kolam (lihat Gambar 3). Benda pertama berada pada posisi 1 meter di atas permukaan kolam. Subjek diminta memberikan bilangan yang tepat untuk benda yang kedua yang berada 2 meter di bawah permukaan kolam. Subjek menggunakan tanda negatif pada posisi benda yang berada di bawah permukaan kolam. Subjek menuliskan -1 dan -2 dinding kolam dan menyebutkan bahwa posisi benda kedua berada pada tempat -2 (lihat Gambar 3). Meski yang dipertanyakan adalah posisi akhir, 2 meter di bawah permukaan air, subjek tetap menuliskan titik -1 sebelum menuliskan -2 . Artinya subjek memiliki pemahaman bahwa -1 terletak sebelum bilangan -2 di bawah permukaan kolam dan menampilkannya pada saat menghitung ke bilangan -2 . 


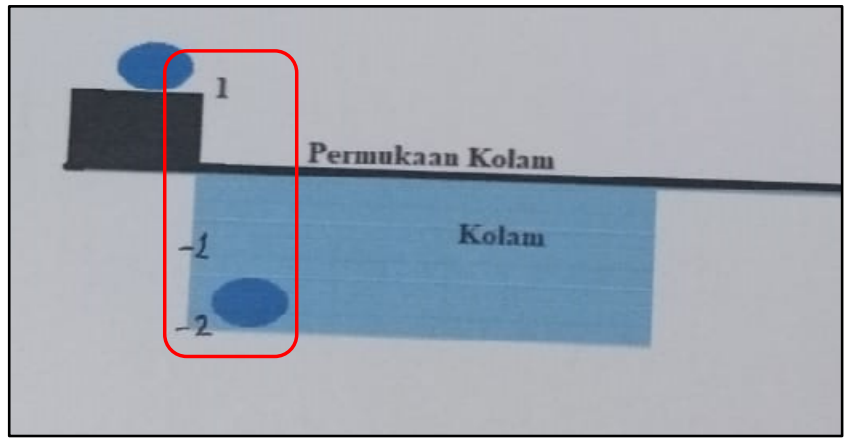

Gambar 3. Pemaknaan posisi benda di bawah permukaan air untuk bilangan negatif

\section{Bilangan Bulat Negatif Sebagai Invers Penjumlahan Bilangan Asli}

Subjek mengetahui bahwa bilangan bulat positif ditambah dengan invers-nya hasilnya adalah 0 . Beberapa kali diberikan penjumlahan antara bilangan bulat positif dengan invers penjumlahannya atau sebaliknya, selalu dijawab 0 . Gambar 4 menyajikan beberapa pertanyaan tentang penjumlahan bilangan bulat positif dengan invers penjumlahannya.

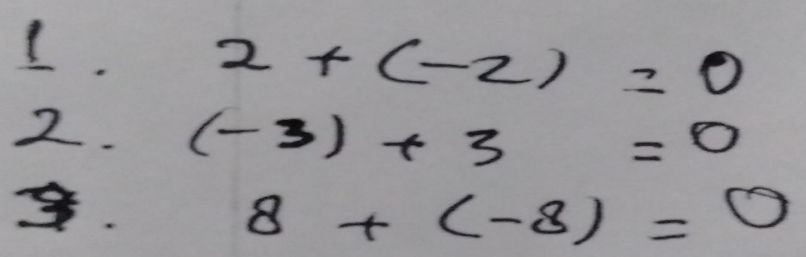

Gambar 4. Hasil kerja subjek untuk bilangan bulat negatif sebagai invers penjumlahan bilangan asli

Subjek melakukan perhitungan dengan bantuan garis bilangan. Peneliti meminta subjek menuliskan jawaban untuk permasalahan yang umum yakni $a+(-a)$. Gambar 5 menyajikan hasil jawaban subjek.

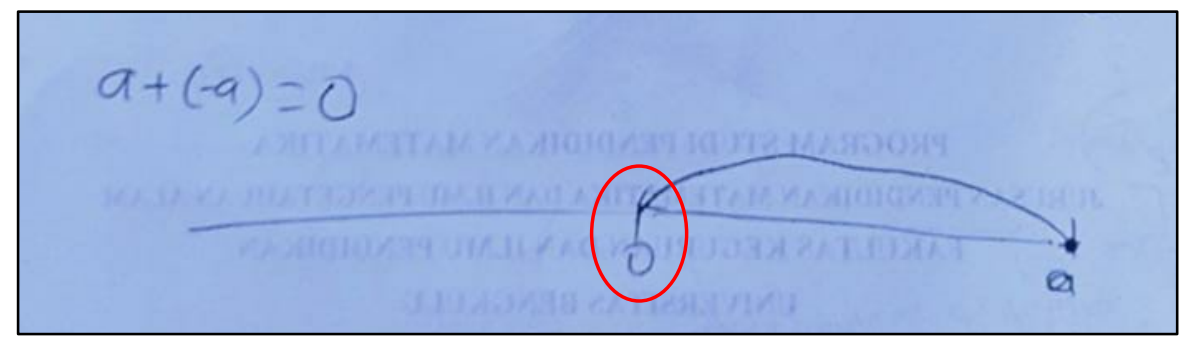

Gambar 5. Hasil kerja subjek untuk $a+(-a)=0$

Subjek menggambar garis bilangan kemudian menulis titik $a$ di sisi bilangan bulat positif, sebagai posisi untuk bilangan $a$ yang akan ditambahkan, kemudian melanjutkan melangkah ke kiri sebesar $a$ lagi, yakni sampai di bilangan 0 . Selanjutnya, subjek menuliskan 0 sebagai jawaban dari $a+(-a)$. subjek memahami peubah $a$ sebagai sebuah lambang bilangan bulat yang bisa berapa saja dan selalu positif. Begitu juga bahwa untuk $-a$, sebuah bilangan bulat berapa saja dan selalu negatif.

\section{Bilangan Negatif dan Simbol Operasi Pengurangan}

Subjek mampu membedakan antara bilangan negatif dengan simbol operasi pengurangan dengan tepat. Subjek menentukan bilangan negatif dengan mengartikannya pada garis bilangan. Bilangan yang berada pada sisi kiri bilangan 0 sebagai bilangan bulat negatif dan bilangan pada sisi kanan dari bilangan 0 sebagai bilangan positif. Gambar 6 menyajikan jawaban subjek terhadap pertanyaan tentang kemampuan membedakan bilangan bulat negatif dengan operasi pengurangan. 


\section{Beri garis bawah pada bilangan bulat negatif dibawah in': \\ 1. $7-8=-1$ \\ 2. $-2+3=$ \\ 3. $-1-4=-5$ \\ 5. $-4-(-7)=3$ \\ 4. $-3+(-1)=-4$ \\ 6. $-1+(-2)=-3$}

Gambar 6. Hasil pengerjaan subjek untuk perbedaan bilangan bulat negatif dengan simbol operasi pengurangan

Selanjutnya melalui wawancara diperoleh bahwa subjek menyatakan bahwa bilangan 0 bukan bilangan positif dan bukan juga bilangan bulat negatif karena bilangan 0 disebut sebagai "batas bilangan negatif dan bilangan bulat positif". Bilangan bulat negatif dimulai-1 sampai ke sisi kiri garis bilangan (disebut dengan kata "sampai tak terhitung di sebelah kiri"). Bilangan bulat positif dimulai dari 1 sampai ke sisi kanan garis bilangan (disebut dengan kata "sampai tak terhitung di sebelah kanan"). Kata tak terhitung yang dimaksud subjek dapat diartikan sebagai bilangan bulat yang besar sekali untuk bilangan positif dan bilangan bulat yang kecil sekali untuk bilangan bulat negatif.

\section{Letak Bilangan Bulat Negatif pada Garis Bilangan Bulat}

Subjek mengetahui bahwa untuk setiap bilangan bulat positif, ada invers penjumlahan dari bilangan tersebut dan disebut sebagai bilangan bulat negatif. Sehingga saat diberikan sebuah pernyataan bahwa jika pada garis bilangan ada bilangan bulat positif $A$ yang terletak sebelah kanan bilangan 0 , maka subjek mampu menuliskan di mana letak $-A$ sebagai invers penjumlahan dari bilangan tersebut. Gambar 7 menyajikan bentuk jawaban subjek.

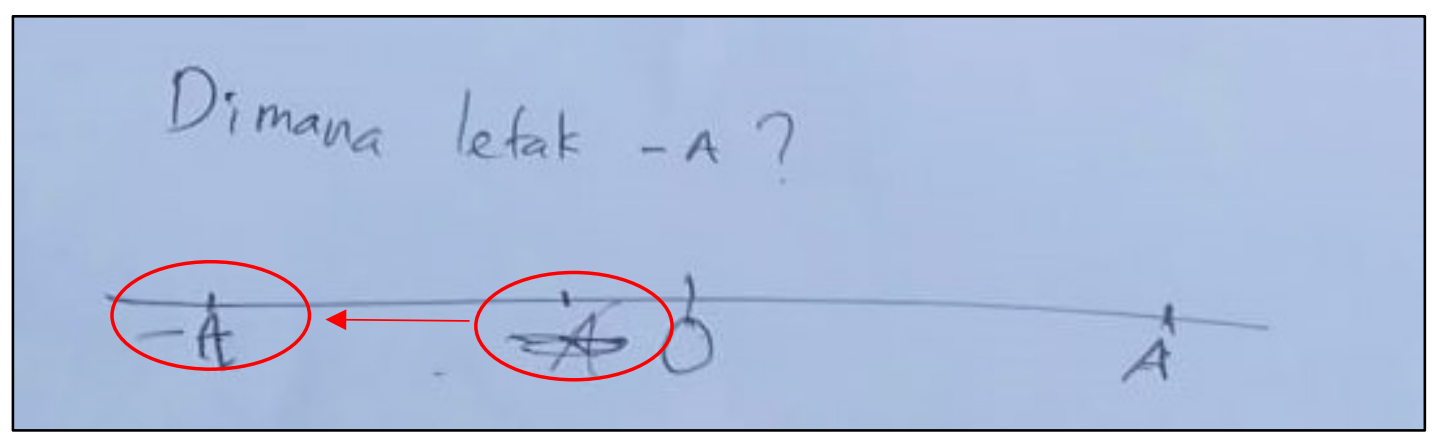

Gambar 7. Hasil kerja subjek tentang posisi bilangan $-A$ pada garis bilangan

Awalnya subjek menulis $-A$ berdekatan dengan bilangan 0 , setelah ditanya kenapa berada di sebelah kiri dan dekat dengan bilangan 0 , subjek mengubah jawabannya dengan cepat dan menuliskan $-A$ menjauh dari bilangan 0 dengan alasannya jaraknya harus sama antara bilangan 0 ke bilangan $A$ dengan 0 ke $-A$. Dikatakan juga bahwa tempat awal adalah bilangan yang lain lagi.

Peneliti tertarik untuk mengetahui lebih lanjut terutama dalam hal penulisan peubah pada garis bilangan tersebut. Peneliti menuliskan bilangan bulat negatif pada garis bilangan dengan lambang $c$ dan meminta subjek menuliskan di mana letak invers penjumlahan dari bilangan $c$ tersebut pada garis bilangan. Subjek menjawab dengan ragu-ragu kemudian mengatakan tidak ada. Subjek mengatakan bahwa peneliti salah tempat dalam menuliskan bilangan c. Peneliti memberikan dorongan bahwa bilangan c sudah benar di sana, di mana letak invers penjumlahan bilangan tersebut? Subjek menulis tanda "-" pada sisi kanan bilangan c (lihat Gambar 8) dan menyebutnya tetap di sana dan berhimpit. Artinya subjek tetap menyatakan bahwa $c$ adalah bilangan positif sehingga $-c$ adalah bilangan negatif.

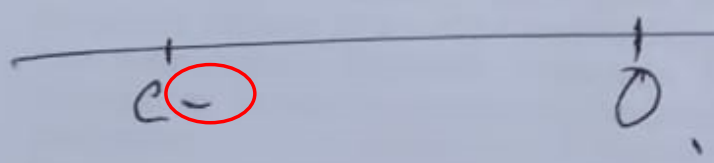

Gambar 8. Hasil kerja subjek untuk menentukan - $c$ pada garis bilangan 


\section{Urutan Bilangan Bulat}

Subjek memahami bilangan bulat seperti angka-angka yang ada pada penggaris. Bilangan bulat negatif diumpamakan seperti bilangan pada penggaris yang dibalik arahnya diletakkan pada sisi kiri bilangan 0 , dan bilangan bulat positif seperti angka pada penggaris yang diletakkan di sisi kanan bilangan 0 . Kedua penggaris terhubung dan menyatu pada titik bilangan 0. Subjek memberikan penjelasan seperti pada Gambar 9.
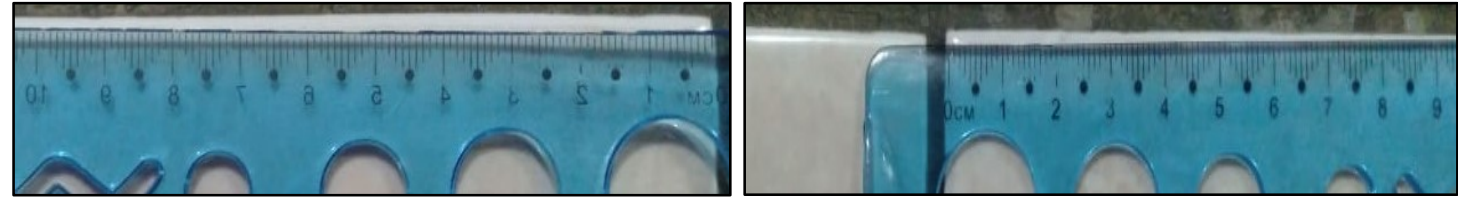

Gambar 9. Penggambaran urutan bilangan dengan penggaris oleh subjek

Garis-garis pada bagian penggaris tidak menjadi perhatian subjek, yang diperhatikannya hanyalah bilangan-bilangannya saja. Subjek menyatakan bahwa bilangan sebelah kiri adalah bilangan yang memiliki tanda negatif. Semakin besar nilai suatu bilangan positif maka semakin ke kiri dari bilangan 0 untuk negatif bilangan tersebut. Subjek menyebutkan dengan kalimat "semakin besar angkanya semakin kecil tanda kurangnya". Dapat dipahami bahwa yang dimaksud subjek adalah semakin besar bilangan bulat positif tersebut, semakin kecil invers bilangan tersebut. Dari kalimat tersebut, subjek memberikan arti urutan bahwa negatif bilangan 1 triliun lebih kecil dari negatif bilangan 1 milyar. Subjek mengakui bahwa gurunya pernah berkata bahwa bilangan 1 triliun lebih dari bilangan 1 milyar. Padahal subjek tidak mengetahui persis lambang bilangan untuk 1 triliun dan 1 milyar. Saat ini subjek hanya mampu dan benar dalam menuliskan lambang bilangan 1 juta. Untuk lambang bilangan 1 milyar dan 1 triliun, subjek menyebutnya bilangan yang besar sehingga tidak mengetahui lambangnya, tapi antara dua bilangan tersebut, 1 triliun adalah bilangan yang terbesar.

Subjek menyebutkan banyak titik-titik pada garis bilangan di sebelah kanan bilangan 0 adalah "tak terhitung". Begitu juga banyak titik-titik sebelah kiri dari bilangan 0 adalah "tak terhitung". Hanya saja bilangan di sebelah kiri dan di sebelah kanan bilangan 0 dibedakan oleh tanda negatif saja.

Untuk beberapa kali, subjek menggunakan pinggir ruangan sebagai representasi lain dari penggaris sebagai garis bilangan. Sisi kanan dari subjek yang menghadap dinding sebagai titik-titik bilangan bulat positif dan sisi kiri sebagai titik-titik bilangan bulat negatif. Subjek tetap menjaga jarak antar titik-titik bilangan yang dibayangkan pada pinggir ruangan seperti titik-titik pada penggaris. Namun, tidak terjadi pergantian arah meski subjek menghadap ke arah yang berlawanan dengan alasan bahwa titik-titik bilangan sudah ada di pinggir ruangan tersebut. Akibatnya, subjek tidak menggunakan istilah sebelah kanan dan sebelah kiri lagi sebagai tempat bilangan bulat pada pinggiran ruangan tersebut. Perkiraan pemaknaan garis bilangan pada dinding bagi subjek dapat dilihat pada Gambar 10.

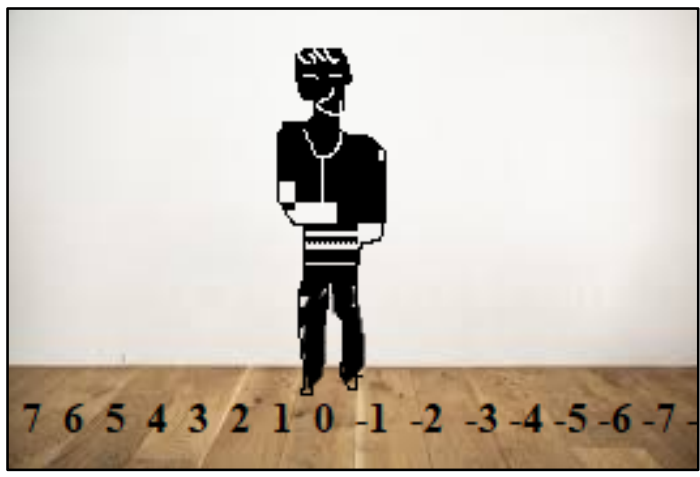

Gambar 10. Pemaknaan garis bilangan pada dinding bagi subjek

\section{Operasi Penjumlahan pada Bilangan Bulat dan Maknanya}

Pada operasi penjumlahan dua bilangan bulat, subjek mampu menjawab dengan tepat semua pertanyaan. Untuk kedua bilangan adalah bilangan bulat positif dan bilangan yang mudah menurut subjek, subjek menghitung secara langsung. Contoh bilangan yang mudah menurut subjek mudah adalah penjumlahan 3 dan 5, 58 dan 17, 266 dan 28. Apabila kedua bilangan adalah bilangan bulat positif dan bilangan yang sulit untuk dihitung langsung menurut subjek, subjek menggunakan penjumlahan bersusun ke bawah. 
Untuk operasi penjumlahan yang melibatkan bilangan bulat negatif, subjek melakukan perhitungan dengan garis bilangan. Untuk bilangan yang sederhana menurut subjek, subjek cukup menghitung dengan membayangkan garis bilangan dalam kepala saja. Jika kedua bilangan adalah bilangan bulat positif, maka dilakukan penjumlahan secara langsung. Jika salah satu bilangan adalah bilangan bulat negatif, maka subjek melakukan perbandingan dari nilai mutlak kedua bilangan. Nilai mutlak yang dimaksud adalah bilangan tanpa tanda "-". Jika dari hasil perbandingan, nilai mutlak bilangan bulat negatif lebih dari bilangan bulat positif, maka subjek mengeluarkan kata "tidak cukup", yang berarti hasil operasi adalah bilangan bulat negatif dari selisih nilai mutlak kedua bilangan. Jika sebaliknya, subjek mengeluarkan kata "lebih" yang berarti hasil operasi adalah bilangan bulat positif yakni selisih dari nilai mutlak kedua bilangan.

Jika kedua bilangan pada operasi penjumlahan adalah bilangan bulat negatif, maka subjek menyebut kedua bilangan "bertanda sama". Subjek melakukan perhitungan layaknya penjumlahan dua bilangan bulat positif dan memberi tanda negatif pada hasil akhir perhitungan. Namun, jika kedua bilangan adalah bilangan bulat positif, subjek tidak menyebutkan kata "bertanda sama". Dari wawancara diperoleh bahwa untuk bilangan bulat positif tidak membutuhkan penanda seperti bilangan bulat negatif karena sudah terbiasa.

Untuk bilangan yang tidak sederhana menurut subjek, subjek menghitung dengan menuliskan garis bilangan pada kertas jawaban dan melakukan prosedur bergerak maju atau mundur pada titik bilangan yang akan dijumlahkan. Maju diartikan sebagai bergerak ke arah kanan titik bilangan sebanyak bilangan penambah. Maju dilakukan subjek jika bilangan penambah adalah bilangan bulat positif. Gambar 11 menyajikan prosedur yang dilakukan subjek untuk perhitungan $5+3$.

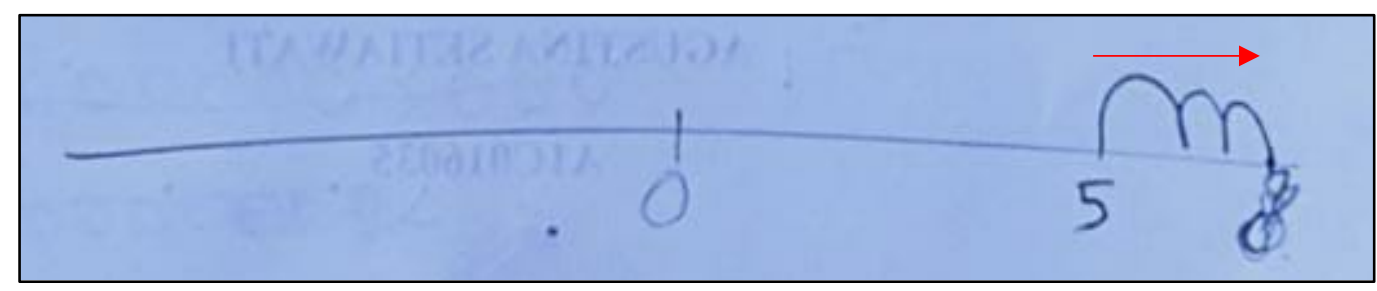

Gambar 11. Hasil kerja subjek untuk perhitungan $5+3$

Pada Gambar 11, terlihat bahwa subjek memulai dari titik 5 kemudian maju 3 titik dan berakhir pada titik 8, sehingga hasil operasi dari $5+3=8$. Arah bergerak lompatan ditunjukkan oleh tanda panah merah pada Gambar 11 .

Untuk prosedur bergerak mundur, subjek mengartikan sebagai bergerak ke arah kiri titik bilangan sebanyak nilai mutlak bilangan penambah. Mundur dilakukan subjek jika bilangan penambah adalah bilangan bulat negatif. Gambar 12 menyajikan prosedur yang dilakukan subjek untuk perhitungan $7+(-2)$.

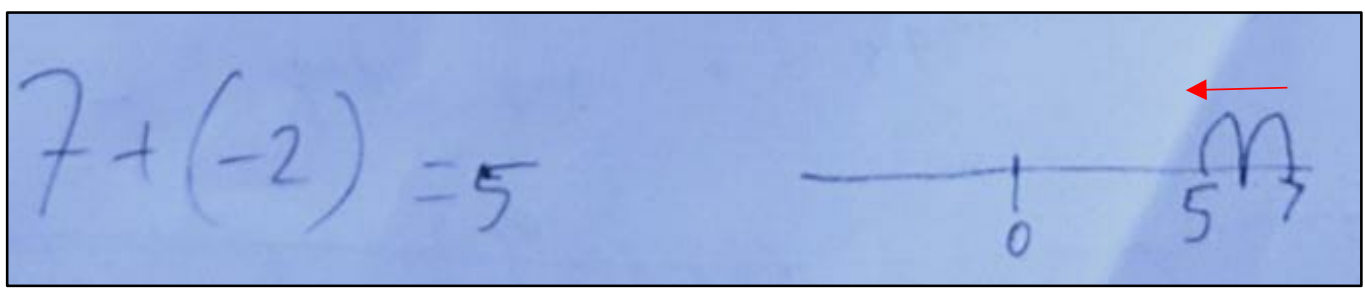

Gambar 12. Hasil kerja subjek untuk perhitungan $7+(-2)$

Sesuai arah tanda panah merah pada Gambar 12, subjek memulai dari titik 7, kemudian mundur sebanyak 2 titik dan berakhir pada titik 5 , sehingga hasil operasi dari $7+(-2)=5$.

\section{Operasi Pengurangan pada Bilangan Bulat dan Maknanya}

Pada operasi pengurangan, subjek melakukan perhitungan berbantuan garis bilangan dengan prosedur "jarak", yaitu menghitung jarak dari kedua bilangan dan menentukan tanda positif atau negatif dengan cara membandingkan bilangan yang dikurang dengan bilangan pengurang atau melihat posisi bilangan yang dikurang dengan bilangan pengurang pada garis bilangan. Kadang subjek menentukan tanda bilangan dengan melakukan perbandingan kedua bilangan tanpa garis bilangan, pada lain waktu subjek menentukan tanda bilangan dengan melihat posisi bilangan yang dikurang dengan bilangan pengurang. 
Penentuan tanda bilangan dengan membandingkan bilangan yang dikurang dengan bilangan pengurang adalah dengan cara melihat hasil bilangan yang terbesar dari kedua bilangan tersebut. Jika bilangan yang dikurangkan lebih dari bilangan pengurang, maka hasil hitung operasinya bertanda positif. Jika bilangan yang dikurangkan kurang dari bilangan pengurang, maka hasil hitung operasinya bertanda negatif.

Untuk menentukan tanda bilangan pada hasil hitung operasi, subjek sering melakukan perhitungan langsung pada bilangan yang dapat dihitung secara sederhana menurut subjek. Subjek tidak melakukan perhitungan dengan garis bilangan. Gambar 13 menyajikan contoh perhitungan pada operasi pengurangan yang dilakukan subjek tanpa menggunakan garis bilangan.

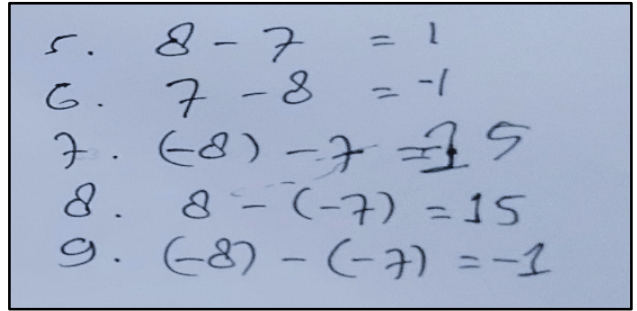

Gambar 13. Hasil kerja subjek untuk operasi hitung pengurangan

Untuk hasil perhitungan nomor 5 dan 8 bertanda positif karena subjek memperoleh hasil perbandingan bilangan yang dikurang lebih dari bilangan pengurang. Untuk hasil perhitungan nomor 6, 7, dan 9 bertanda negatif karena subjek memperoleh hasil perbandingan bilangan yang dikurangi kurang dari bilangan pengurang.

Penentuan tanda bilangan hasil hitung operasi pengurangan dengan melihat posisi bilangan yang dikurang dengan bilangan pengurang pada garis bilangan adalah dengan melihat arah pergerakan dari bilangan yang dikurang dengan bilangan pengurang. Jika pergerakan dari bilangan yang dikurangkan ke bilangan pengurang bergerak dari sisi kanan ke sisi kiri, maka hasil hitung operasinya bertanda positif. Jika pergerakan dari bilangan yang dikurangkan ke bilangan pengurang bergerak dari sisi kiri ke sisi kanan, maka hasil hitung operasinya bertanda negatif. Jika digambarkan prosedur ini secara ringkas pada satu garis bilangan, maka dapat dibuat seperti Gambar 14.

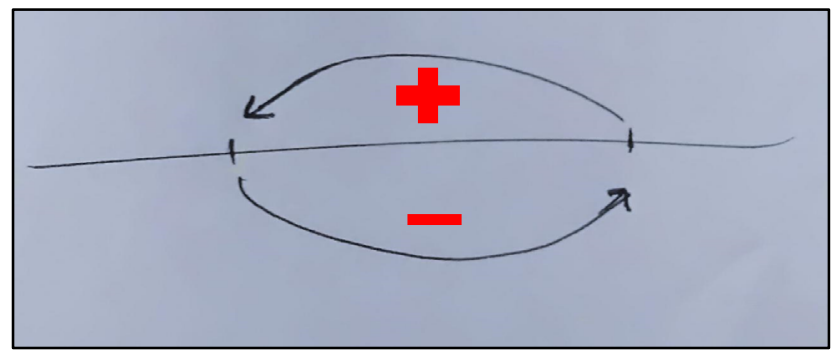

Gambar 14. Ringkasan prosedur penentuan tanda bilangan pada operasi pengurangan

Pergerakan dari bilangan yang dikurangkan ke bilangan pengurang bergerak dari sisi kanan ke sisi kiri sering ditandai dengan lompatan perhitungan jarak di atas garis bilangan. Seperti 7-2, subjek melakukan 5 kali lompatan di atas garis bilangan karena pergerakan lompatan dilakukan dari sisi kanan yakni titik 7 sampai ke sisi kiri yakni titik 2, sehingga hasil dari 7-2 = 5 (lihat Gambar 15).

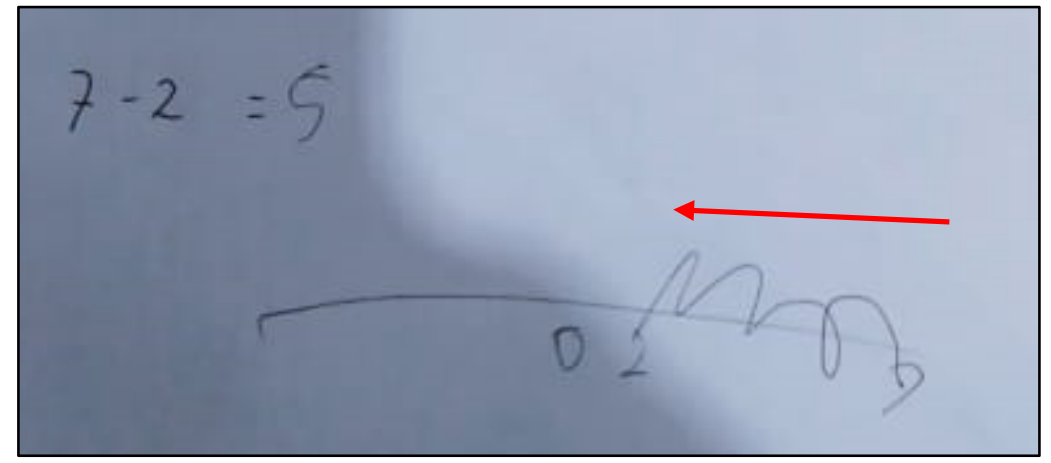

Gambar 15. Prosedur perhitungan 7-2 oleh subjek 
Pergerakan dari bilangan yang dikurangkan ke bilangan pengurang bergerak dari sisi kiri ke sisi kanan sering ditandai dengan lompatan perhitungan jarak di bawah garis bilangan. Seperti $(-1)-2$, subjek melakukan 3 kali lompatan di bawah garis bilangan karena pergerakan lompatan dilakukan dari sisi kiri yakni titik - 1 sampai ke sisi kanan yakni titik 2, sehingga hasil dari $(-1)-2=-3$ seperti yang ditunjukkan oleh Gambar 16.

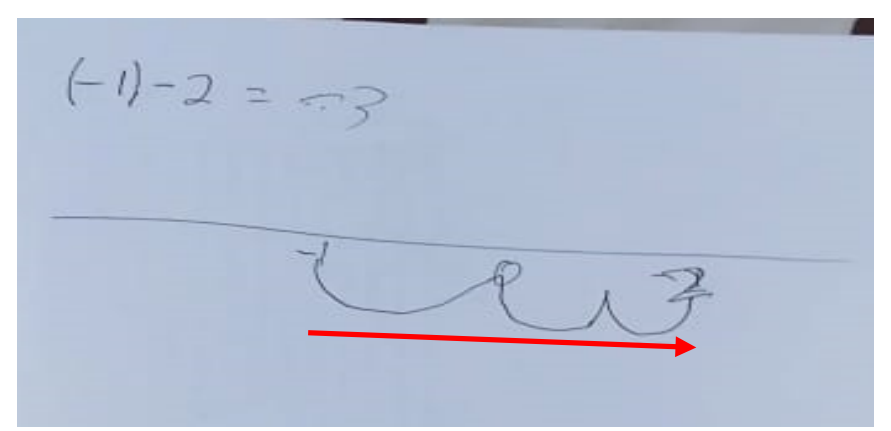

Gambar 16. Prosedur perhitungan (-1) - 2 oleh subjek

\section{PEMBAHASAN}

Pada materi bilangan cacah yang sudah dipelajari oleh subjek, terdapat konsep bahwa bilangan cacah tidak terbatas. Konsep ini sudah dimiliki oleh subjek dengan baik. Ini terlihat dari pernyataan subjek bahwa banyaknya bilangan bulat positif “tak terhitung". Subjek merefleksikan konsepsi yang dimilikinya ke bilangan bulat negatif. Akibatnya pemaknaan bilangan bulat negatif oleh subjek lebih terlihat ketika diminta untuk diartikan dalam kegiatan sehari-hari. Subjek menggunakan istilah "yang kurang" untuk nilai bilangan bulat negatif untuk kehidupan seharihari. "Yang kurang" dapat diartikan sebagai nilai bilangan yang kurang dari bilangan 0. Begitu juga untuk istilah "utang" diartikan sebagai kekurangan nilai bilangan dari bilangan 0 . Sebelum penelitian, subjek tidak menyatakan bilangan bulat negatif dengan kata utang, namun dari wawancara, subjek merasakan bahwa bilangan bulat negatif dapat juga dikatakan dengan utang untuk penerapan dalam kehidupan sehari-hari. Sesuai dengan hasil Sugiatno (2013) yang menyatakan bahwa konsepsi siswa tentang bilangan bulat bersifat pengalaman pribadi siswa tersebut. Dalam keseharian, subjek mendapatkan pengalaman belajar dari orang tua dan kakak terutama tentang bilangan bulat. Bilangan bulat banyak terlibat dalam keseharian seperti perhitungan dalam permainan, perhitungan uang belanja yang diberikan per bulan, menjawab pertanyaan yang muncul dari kekritisan subjek tentang sesuatu hal yang ditemukan di keseharian, keterlibatan subjek dalam pelajaran matematika kakaknya karena kondisi pembelajaran dari rumah. Selain itu, beberapa teori diperoleh dari bimbingan belajar sempoa tentang operasi bilangan bulat seperti pernyataan bahwa bilangan asli tak berbatas, satu triliun lebih dari satu milyar.

Subjek mengetahui dengan persis bahwa bilangan asli ditambah dengan bilangan negatifnya sama dengan 0 . Subjek melakukan dengan prosedur operasi penjumlahan. Ketika dilakukan penggalian dengan notasi $a$ sebagai bilangan bulat asli, subjek mengetahui bahwa $a+(-a)=0$ setelah subjek bertanya apa itu bilangan $a$, apakah boleh diganti dengan angka 20 atau bilangan lainnya. Dengan kata lain notasi $a$ belum diketahui sebagai sebuah peubah, namun subjek cepat beradaptasi sehingga bisa menjawab bahwa $a$ dan $-a$ adalah bilangan yang saling berlawanan dalam operasi penjumlahan. Untuk kata invers, subjek tidak mengenal sama sekali. Kata invers semata-mata muncul dari peneliti untuk penamaan materi bilangan bulat.

Penggunaan notasi dari peneliti untuk mengganti sebuah bilangan dianggap sebagai sebuah bilangan yang ditutupi. Namun subjek hanya menganggap bahwa untuk notasi $a$, bilangan yang ditutupi hanyalah bilangan bulat positif. Sedangkan untuk bilangan negatif, subjek menggunakan notasi "- " pada peubah tersebut. Ini terlihat dari penulisan $-c$ selalu berada pada sisi sebelah kiri bilangan 0 pada garis bilangan. Jika notasi $c$ dituliskan pada sisi sebelah kiri bilangan 0 pada garis bilangan, dianggap oleh subjek sebagai kesalahan letak bilangan.

Subjek dapat membedakan tanda bilangan dan tanda operasi. Subjek diberikan sebuah pernyataan persamaan yang melibatkan tanda "- " sebagai tanda bilangan dan sebagai tanda operasi. Subjek mampu membedakan karena mengetahui bahwa di antara dua bilangan dalam persamaan ada operasi, sisanya adalah bilangan. Ini terlihat dari cara subjek menjawab yaitu subjek terlebih dulu melihat operasi, baru kemudian bilangan.

Pada garis bilangan, subjek mengetahui letak bilangan bulat negatif. Ini karena subjek sudah mengetahui sistem garis bilangan dan urutan bilangan bulat negatif. Subjek mampu menyatakan bahwa garis bilangan dapat dinyatakan dengan menggabungkan dua penggaris yang saling bertemu di titik 0 . Sebelah kiri bilangannya diberikan 
tanda negatif. Lebih jauh, saat wawancara subjek menggunakan dinding sebagai bayangan garis bilangan karena subjek malas menuliskan cara perhitungan pada kertas. Sambil bermain-main, subjek menyatakan garis-garis batas antar keramik sebagai titik-titik untuk posisi bilangan. Karena ketertarikan subjek ke matematika, terutama bilangan sangat tinggi, subjek sering menggunakan benda di sekitar sebagai representasi apa yang sedang dipikirkannya. Benda-benda di sekitar itu seperti penggaris dan dinding dengan garis-garis batas antar keramik.

Subjek memberikan pemaknaan dalam membandingkan dua bilangan dengan menyatakan bilangan tersebut ke dalam garis bilangan dan memperoleh bilangan kanan sebagai bilangan besar dan bilangan sebelah kiri sebagai bilangan kecil. Artinya subjek menyatakan pemaknaan dengan menggunakan bahasa kiri dan kanan. Hal ini tak jauh berbeda dengan penelitian yang dilakukan Bofferding dan Farmer (2019) di Midwestern Amerika Serikat tahun 2017 terhadap siswa kelas 2 dan kelas 4. Dalam penelitiannya, mereka memberikan pemaknaan bilangan kecil dengan istilah "coldest" dan "hottest" untuk sebaliknya. Namun, dari hasil penelitiannya diperoleh bahwa hanya untuk bilangan yang melibatkan bilangan negatif dan positif saja siswa mudah melakukannya. Untuk bilangan yang sama-sama positif atau negatif, siswa tersebut masih memiliki kesulitan dalam membandingkannya.

Piaget (1959) membagi kegunaan bahasa anak-anak, salah satunya adalah anak berbicara dengan diri sendiri untuk membuat pikiran bekerja keras, dia melakukannya bukan untuk berbicara dengan siapa pun. Kita dapat menyatakan bahwa subjek mengucapkan kata "berlebih" dan "berkurang" untuk menjawab pertanyaan peneliti, termasuk dalam pembagian yang dimaksud oleh Piaget. Subjek mengucapkan kata tersebut untuk membantu dia berpikir bahwa hasil dari operasi apakah berbentuk bilangan positif atau negatif. Pada literatur, bilangan negatif dan operasinya sering muncul dalam permainan untung dan rugi, utang, tangga naik turun, ke ruang bawah tanah, termometer naik dan turun, dan di bawah titik beku (Freudenthal, 2002). Ini sesuai dengan pola yang dikenali subjek untuk bilangan bulat negatif setelah dilakukan permainan. Subjek mengenali utang dan posisi di bawah kolam sebagai penggunaan bilangan bulat negatif.

Dalam wawancara, sering sekali peneliti kesulitan mengartikan kata-kata yang disampaikan subjek untuk menjawab pertanyaan yang diberikan. Namun, peneliti mencoba mencari padanan kata yang diperkirakan sama dengan apa yang dimaksud oleh subjek. Ini sesuai dengan pernyataan dari Vygotsky (1986) bahwa, dialog yang terjadi antara orang dewasa dengan anak-anak untuk obyek yang sama, sering memberikan interpretasi yang berbeda, karena anak-anak memandang obyek berdasarkan kondisi dasar, sedangkan orang dewasa memandang secara konseptual.

Tidak berbeda dengan penelitian Whitacre et al. (2017) tentang perbandingan bilangan bulat, bahwa ada tiga cara penalaran siswa dalam membandingkan bilangan yakni berdasarkan besaran bilangan, berdasarkan urutan bilangan, dan yang lain, subjek melakukan perbandingan bilangan dengan melihat urutan bilangan yang dibayangkan dalam garis bilangan. Bilangan yang paling kiri adalah bilangan yang terkecil atau sebaliknya.

Kualitas buku teks berpengaruh terhadap strategi siswa dalam membentuk prinsip aritmetika siswa (Sievert et al., 2021). Dalam perhitungan operasi pengurangan pada bilangan bulat, subjek melakukan perhitungan "jarak" dari kedua bilangan dengan menggunakan garis bilangan. Diprediksi subjek mengenali prosedur ini dari prosedur perhitungan gradien suatu garis lurus pada koordinat Cartesius yang sedang dipelajari oleh kakaknya. Pada akhirakhir ini materi kakak subjek adalah persamaan garis lurus, dan salah satu sub materinya menghitung gradien. Pada perhitungan gradien jika diketahui dua titik yang digambarkan pada koordinat Cartesius, kakak subjek terlihat melakukan perhitungan operasi pengurangan antar dua nilai $x$ dan antar dua nilai $y$.

Interpretasi tanda kurang dibutuhkan siswa sekurang-kurangnya dalam tiga kegunaan yaitu sebagai pengurangan, sebagai indikator bilangan negatif, dan sebagai tanda lawan dari bilangan (Bryant et al., 2020). Namun, masih ada siswa yang salah dalam membedakan tanda kurang sebagai pengurangan dan sebagai indikator bilangan negatif. Seorang siswa kelas 5 di Amerika Serikat menyatakan sama pernyataan antara (-9) -8 dengan $(-9)+8$ (Wessman-Enzinger, 2019). Kesalahan ini terjadi karena siswa lupa pada konsep perubahan tanda kurang menjadi tanda tambah yang biasa dilakukannya. Masih dalam penelitian Wessman-Enzinger, Jace, salah satu siswa kelas 5 menyatakan bahwa untuk perhitungan $12+(-16)$ sama dengan perhitungan bersusun ke bawah $16+(-12)=-4$. Terlihat bahwa ada kesulitan bagi siswa dalam menghafal prosedur operasi yang melibatkan bilangan negatif.

Teknik operasi pengurangan yang dilakukan subjek belum ada ditemukan dalam artikel lain. Dengan teknik ini, subjek tidak membutuhkan sederet hafalan tentang teknik operasi pengurangan pada bilangan bulat. Sering kesalahan yang dilakukan siswa dalam perhitungan operasi pengurangan adalah salah dalam melakukan pergerakan maju mundur pada garis bilangan. Contoh pada perhitungan $(-8)+6-9$, siswa kelas VII masih salah dalam melakukan loncatan pada garis bilangan (Mulyati, 2018). Kesalahan ini diakibatkan oleh teknik penjumlahan dan 
pengurangan yang mirip, perbedaan hanya pada arah loncatan. Meloncat ke arah kiri jika bilangan positif dan operasinya adalah pengurangan dan sebaliknya jika bilangan negatif untuk operasi yang sama. Begitu juga dengan operasi penjumlahan, meloncat ke kanan jika bilangannya positif, dan ke kirijika bilangannya negatif. Tentu hafalan ini membutuhkan latihan yang banyak agar siswa mampu membedakannya dengan baik.

Dari berbagai daerah di Indonesia dilaporkan bahwa kemampuan siswa meningkat dengan penggunaan Blok Dienes untuk operasi pengurangan pada siswa (Al Baity et al., 2015; Ananda, 2017; Yulastri, 2017). Berbeda dengan yang dilakukan oleh siswa lain untuk teknik operasi pengurangan, subjek tidak melakukan loncatan dari posisi bilangan yang akan dikurangkan. Subjek melakukan perhitungan jarak antara dua bilangan yang dioperasikan dan memberikan tanda bilangan dengan cara membandingkan kedua bilangan. Jika bilangan besar dikurang kecil, maka tandanya positif dan negatif untuk sebaliknya. Minimal, terjadi pengurangan prosedur yang dilakukan subjek dibandingkan dengan yang dilakukan oleh siswa selama ini.

Vygotsky (1986) menyebutkan bahwa konsep yang terbentuk dalam pikiran anak-anak adalah jenis pseudoconcept, meskipun secara fenotif menyerupai konsep orang dewasa, namun secara psikologis sangat berbeda dengan konsep yang sebenarnya pada hakikatnya. Konsepsi yang dimiliki subjek, sepertinya sama dengan yang dimiliki orang lain pada umumnya. Hanya saja subjek mengenali konsep bilangan bulat lebih cepat dari semestinya yang ada dalam kurikulum. Ini dipengaruhi oleh lingkungan subjek. Interaksi anggota keluarga dengan subjek yang banyak memberikan pengetahuan yang benar, sangat memotivasi subjek untuk terus menggali informasi dengan apa yang terjadi di keseharian subjek, meskipun materi tersebut belum dipelajari di sekolah. Bimbingan belajar memberikan pengetahuan baru yang tidak diperoleh dari sekolah. Fasilitas berupa sumber belajar dari internet menjadi alternatif pemicu penambahan motivasi penggalian informasi. Dari gaya bahasa informasi yang ada pada internet membuat subjek tertarik dengan permasalahan yang tersaji. Semua intervensi dari lingkungan ini saling mendukung dalam penambahan konsepsi subjek tentang bilangan bulat.

Peneliti berharap hasil penelitian ini dapat berkontribusi bagi guru dalam menyikapi pembelajaran bilangan bulat. Dengan adanya temuan bahwa siswa dapat memiliki konsepsi yang baik tentang bilangan bulat meski belum dipelajari disekolah, guru dapat melanjutkan konsepsi yang telah dimiliki siswa daripada guru membangun pengetahuan dengan anggapan siswa belum memiliki konsepsi sama sekali. Guru diharapkan melakukan penggalian konsepsi siswa tentang materi yang akan dipelajari sebelum memulai pembelajaran pada materi tersebut.

\section{SIMPULAN}

Berdasarkan hasil penelitian dan pembahasan, dapat disimpulkan bahwa subjek memiliki konsepsi tentang bilangan bulat sebagai berikut: 1) menggunakan istilah "kurang", "utang", atau "posisi di bawah permukaan" untuk memaknai bilangan bulat negatif, 2) bilangan bulat negatif dapat diartikan sebagai invers penjumlahan bilangan asli, 3) ada perbedaan antara simbol negatif dengan simbol operasi pengurangan, 4) bilangan bulat negatif berada di sebelah kiri bilangan 0 pada garis bilangan, 5) bilangan bulat negatif terkecil berada di sebelah kiri bilangan bulat negatif lainnya seperti bilangan-bilangan pada penggaris dan mampu menggunakan dinding sebagai pengganti garis bilangan, 6) menggunakan istilah "maju" atau "mundur" untuk mengoperasikan penjumlahan bilangan bulat, dan 7) menggunakan istilah "jarak", "lompatan di atas garis bilangan", dan "lompatan di bawah garis bilangan" untuk mengoperasikan pengurangan bilangan bulat. Temuan ini sangat menarik di tengah banyaknya pandangan bahwa faktor lingkungan dianggap berpengaruh negatif bagi siswa. Siswa pada penelitian ini memperoleh penguasaan konsep bilangan bulat yang baik melalui pengaruh dari lingkungan, tanpa andil pengaruh proses belajar dari sekolah. Pada penelitian ini tidak digali pengaruh masing-masing lingkungan siswa terhadap konsepsi masingmasing materi. Diharapkan penelitian selanjutnya dapat menggali lebih dalam seberapa besar pengaruh masingmasing lingkungan terhadap konsepsi siswa tentang materi yang telah dimiliki, pengaruh mana dari lingkungan yang memberikan sumbangan besar terhadap konsepsi siswa dan bagaimana meningkatkan pengaruh tersebut.

\section{UCAPAN TERIMAKASIH}

Terima kasih kepada subjek yang telah menyampaikan semua yang dimiliki dalam pikirannya dalam hal bilangan bulat. Terima kasih kepada Lembaga Pengelola Dana Pendidikan Kementerian Keuangan yang telah memberikan pendanaan dalam studi program doktor ini. Terima kasih juga kami sampaikan kepada Reviewer untuk masukan yang sangat berharga dalam penyempurnaan tulisan ini. 


\section{DAFTAR PUSTAKA}

Aji, W.P. (2017). Hubungan fasilitas belajar, kemandirian belajar, dan konsep diri terhadap prestasi belajar matematika siswa SMP. Ekuivalen-Pendidikan Matematika, 28(1), 92-97. https://doi.org/10.37729/ekuivalen.v28i1.3908

Al Baity, S. A. Z., Margiati, M., \& Kresnadi, H. (2015). Peningkatan aktivitas dan hasil belajar siswa pembelajaran matematika menggunakan blok model dienes di kelas 3. Jurnal Pendidikan dan Pembelajaran Khatulistiwa, 4(1), 1-11. http://jurnal.untan.ac.id/index.php/jpdpb/article/view/8911/8857

Ananda, R. (2017). Peningkatan hasil belajar siswa pada materi operasi pengurangan bilangan cacah dengan menggunakan blok dienes siswa kelas I SDN 016 Bangkinang Kota. Jurnal Cendekia: Jurnal Pendidikan Matematika, 1(1), 1-11. https://doi.org/10.31004/cendekia.v1i1.2

Astawa, I. K. P., Suarjana, I. M., \& Murda, I. N. (2016). Analisis kemampuan siswa dalam menyelesaikan operasi bilangan bulat pada siswa kelas V SD. Mimbar PGSD, 4(1), 1-11. http://dx.doi.org/10.23887/jjpgsd.v4i2.7697

Bofferding, L., \& Farmer, S. (2019). Most and least: Differences in integer comparisons based on temperature comparison language. International Journal of Science and Mathematics Education, 17(3), 545-563. https://doi.org/10.1007/s10763-018-9880-4

Bryant, D. P., Bryant, B. R., Dougherty, B., Roberts, G., Pfannenstiel, K. H., \& Lee, J. (2020). Mathematics performance on integers of students with mathematics difficulties. Journal of Mathematical Behavior, 58(June 2019), 1-13. https://doi.org/10.1016/j.jmathb.2020.100776

Creswell, J. W., Hanson, W. E., Plano, V. L. C., \& Morales, A. (2007). Qualitative research designs: Selection and implementation. The Counseling Psychologist, 35(2), 236-264. https://doi.org/10.1177/0011000006287390

Freudenthal, H. (2002). Didactical phenomenology of mathematical structures. Springer. https://doi.org/10.1007/0306-47235-X

Hanun, F. (2010). Pengaruh metode pembelajaran dan kemampuan awal terhadap hasil belajar matematika (studi eksperimen di MAN 3 Jakarta). Widyariset, 13(1), 123-133. http://dx.doi.org/10.14203/widyariset.13.1.2010.123-134

Kemendikbud. (2018) Peraturan menteri pendidikan dan kebudayaan republik Indonesia nomor 37 tahun 2018 tentang perubahan atas peraturan menteri pendidikan dan kebudayaan nomor 24 tahun 2016 tentang kompetensi inti dan kompetensi dasar pelajaran pada kurikulum 2013 pada pendidikan dasar dan pendidikan menengah. https://jdih.kemdikbud.go.id/arsip/Permendikbud Nomor 37 Tahun 2018.pdf

Kusaeri, K. (2017). Terbentuknya konsepsi matematika pada diri anak dari perspektif teori reifikasi dan APOS. JPM: Jurnal Pendidikan Matematika, 1(2), 101-105. https://doi.org/10.33474/jpm.v1i2.244

Mallewai, P. S. (2016). Pengaruh pembelajaran quantum dan kemampuan awal terhadap hasil belajar matematika kelas VIII SMP di Watampone. Jurnal Daya Matematis, 4(1), 20-26. https://doi.org/10.26858/jds.v4i1.2448

Miles, M. B., Huberman, A. M., \& Saldana, J. (2014). Qualitative data analysis: A methods sourcebook (3rd ed.). Sage.

Mulyani, N. M. S., Suarjana, I. M., \& Renda, N. T. (2018). Analisis kemampuan siswa dalam menyelesaikan operasi hitung penjumlahan dan pengurangan bilangan bulat. Jurnal IImiah Sekolah Dasar, 2(3), 266-274. https://doi.org/10.23887/jisd.v2i3.16142

Mulyati, S. (2018). Analisis kesalahan matematika dilihat dari motivasi belajar siswa pada materi operasi hitung bilangan bulat. Ekuivalen-Pendidikan Matematika, 31(1), 84-88. https://doi.org/10.37729/ekuivalen.v31i1.4359

Murjiyanti, M. (2017). Studi komparasi siswa yang mengikuti bimbingan di lembaga bimbingan belajar terhadap pemahaman konsep matematika. Ekuivalen-Pendidikan Matematika, 27(2), 157-162.

https://doi.org/10.37729/ekuivalen.v27i2.3646 
Nuraini, N. L. S., Suhartono, S., \& Yuniawantika, Y. (2016). Kesalahan siswa pada operasi penjumlahan dan pengurangan pecahan di kelas VI Sekolah Dasar. Sekolah Dasar: Kajian Teori dan Praktik Pendidikan, 25(2), 168-175. https://doi.org/10.17977/um009v25i22016p168

Piaget, J. (1959). The language and thought of the child (3rd ed.). Routledge.

Pravitasari, N. (2020). Pengaruh partisipasi aktif orang tua dan penguasaan konsep kognitif matematika terhadap kemampuan berpikir kreatif siswa. Jurnal Studi Guru dan Pembelajaran, 3(2), 206-211. https://doi.org/10.30605/jsgp.3.2.2020.308

Saputri, J. P. (2018). Meningkatkan kemampuan siswa pada pembelajaran operasi hitung penjumlahan dan pengurangan bilangan bulat melalui media kartu bilangan pada kelas V di SDN 24 Temmalebba Kec. Bara Kota Palopo. Pedagogik Journal of Islamic Elementary School, 1(2), 127-138. https://doi.org/10.24256/pijies.v1i2.400

Sievert, H., van den Ham, A. K., \& Heinze, A. (2021). Are first graders' arithmetic skills related to the quality of mathematics textbooks? A study on students' use of arithmetic principles. Learning and Instruction, 71, 1-14. https://doi.org/10.1016/j.learninstruc.2020.101401

Simon, M. A. (2016). Explicating mathematical concept and mathematical conception as theoretical constructs for mathematics education research. Educational Studies in Mathematics, 94, 117-137. https://doi.org/10.1007/s10649-016-9728-1

Sugiatno, S. (2013). Konsepsi siswa mengenai operasi hitung bilangan bulat di kelas V sekolah dasar. Jurnal Pendidikan Dasar, 1(1), 45-57. https://doi.org/10.46368/jpd.v1i1.61

Vygotsky, L. (1986). Thought and language. The MIT Press.

Wessman-Enzinger, N. M. (2019). Grade 5 children's drawings for integer addition and subtraction open number sentences. Journal of Mathematical Behavior, 53, 105-128. https://doi.org/10.1016/j.jmathb.2018.03.010

Whitacre, I., Azuz, B., Lamb, L. L. C., Bishop, J. P., Schappelle, B. P., \& Philipp, R. A. (2017). Integer comparisons across the grades: Students' justifications and ways of reasoning. Journal of Mathematical Behavior, 45, 47-62. https://doi.org/10.1016/j.jmathb.2016.11.001

Yulastri, Y. (2017). Peningkatan hasil belajar operasi pengurangan bilangan cacah melalui blok dienes pada siswa kelas I SDN 21 Batang Anai Kabupaten Padang Pariaman. JPPI (Jurnal Penelitian Pendidikan Indonesia), 3(2), 57-66. https://doi.org/10.29210/02017117 